\title{
Principals' Leadership Practices And Their Influence On Students' Discipline In Public Secondary Schools In Makindu Sub County, Kenya.
}

\author{
"KatoloGideon Nthakyo, GathumbiAnthony Mungai (PhD), \\ KamolaPhoebe Malela \\ Post Graduate Student School of Education, South Eastern Kenya University \\ (Corresponding author), \\ Lecturer, School of Education, South Eastern Kenya University \\ Post Graduate Student School of Education, South Eastern Kenya University
}

\begin{abstract}
The purpose of the study was to investigate the principals' leadership practices and their influence on students' discipline management in public secondary school in Makindu Sub County, Kenya. The study employed descriptive survey research design. The sample comprised of 20 principals, 46 teachers and 197 students who were selected by simple random sampling. Data in the study was collected using questionnaires and descriptive statistics method was used for evaluating headteachers' transformative leadership styles on teachers' job satisfaction. Findings revealed that the principals encouraged open door policy for students to discuss their issues with them, the principals consulted with students before any changes are made to the diet provided by the school and also allowed students to have a say in determining the dress code of the school. Further, the principals set aside specific day(s) in a week for meetings with the students to discuss matters pertaining to the running and of the school. Pearson correlation coefficients computed to find out the relationships between principals leadership practices and student discipline generated strong negative correlation coefficients of $r=-0.961$ with corresponding significant level $(p$-value $=0.000<0.05)$ hence there was significant relationship between principals' consultation of the student council and the number of students' disciplinary cases in school. The study established that principals in their respective secondary schools encouraged open door policy where students were free to see the head of the institution to discuss their problems. The study thus recommends that principals should adopt leadership skills and mechanisms which are aimed at minimizing instances of students' indiscipline. Schools should organize for seminars and workshops for student leaders to acquire skills necessary to help reduce instances of indiscipline in the schools. Principals should adopt collaborative approach which brings all school stakeholders to help address students' indiscipline. Rules for the membership to the student council should be flexible for all students so that they can appreciate and support the students 'councils' leadership.
\end{abstract}

Key words: leadership practices, discipline management, democratic form of school organization.

\section{Introduction}

Worldwide, the fundamental purpose of education is to gain knowledge, inculcate forms of proper conduct and acquire technical competency (Oak, 2008). Education is therefore, fundamental to the success of any country's overall development strategy and a corner stone of economic and social development (Republic of Kenya, 2005). Huczynski (2001) says that the success of an organization depends on the quality of its leadership. He observed that the school principal is the most influential individual in an education institution and that good leadership is the key in holding efficient administration together. Chapman (2003) explains that the school principal is viewed as the primary decision maker, facilitator, problem solver and social change agent.

According to Adlam (2003), leadership is a rather complex concept. This is especially true because several approaches have been employed to provide meaning to the term leadership and effectiveness. According to Karunanayake (2012), leadership is a process of influencing followers to achieve the desired expectations. Besides, Sergiovanni (1998) observes that the success of any teaching process is determined upon the quality of students' discipline. Such leadership is imperative for schools to function successfully the way strong leadership is vital for any organization to operate efficiently. Discipline is a function of the administration of institutional leadership at school level.

According to Cotton (2003), governments of the world have found that the following types of behaviours by a principal have a significant impact on student's discipline: the establishment of a clear focus on student learning by having a vision, clear learning goals, and high expectations for learning for all students; interactions and cordial relationships with relevant stakeholders with communication and interaction, emotional and interpersonal support, visibility and accessibility, and parent/community participation; developing a school 
culture conducive to teaching and learning through shared leadership and decision-making, collaboration, risk taking leading to continuous improvements; providing instructional leadership through discussions of instructional issues, observing classroom teaching and giving feedback, supporting teacher autonomy and protecting instructional time; and being accountable for affecting and supporting continuous improvements through monitoring progress and using student progress data for program improvements.

Australia, the United States of America, England and Canada indicate that discipline problems in schools is on the increase. For example in a report entitled, "School Crime, Violence and Safety in U.S Public Schools 2005-2006" published by the U.S Department of Education in 2007 revealed that discipline problems in American schools was common. According to the findings the overall rate of violent incidents for all public schools in U.S was 31 incidents per 1000 students. Some of the common discipline problems included students' threat of physical attack with or without weapon, distribution, possession or use of illegal drugs, bullying, sexual battery and rape (Nolle \& Chandler, 2007).

In United States of America (USA), Gottfredson (2007) found out that in six middle schools in Charles town South Carolina, students lost 7,932 instructional days because of school suspensions in a single academic year due to misconduct in schools. Weeramunda (2008) also did a study in Sri Lanka on discipline in s schools and noted that violence and students' misbehavior is on the increase. Several unrests were reported in 1990, 1996 and 2004. Garagae, (2007) did a study in Botswana and found that discipline problems in schools manifests themselves in various ways such as bullying, vandalism, alcohol and substance abuse, truancy and unwillingness to do homework.

Discipline is a rudimentary ingredient that plays a crucial role in school system, which insists on upholding the moral values of students (Schon, 2003). This view is supported by Blandford (2008) who asserts that discipline is essential if any organization including school has to succeed in the attainment of its goals. The quality of student discipline is an important factor in determining the intellectual outcome of students and schools (Reynolds, 1989). This is because, discipline provides a sense of direction among learners and hence commitment to school values. Moreover, a disciplined student body has a likelihood of increasing teachers' job satisfaction, which is a critical correlate of commitment to institutional goals (Imber \& Neidt, 1990).

In the United Kingdom (UK) the styles principals have used impacted greatly on students' discipline. For example, students' politics has existed since 1880s with the formation of students' representative councils to represent students' interests towards a leadership style used by principals (Koechler, 2002). The movement varied in subject size and success, with all kinds of students in both public and private educational institutions participating. In the United States of America (USA), students' discipline problems have been experienced in the past years. According to Harllinger and Heck (2008), student activism in USA is often understood as associated towards change in the American Educational System. Currently, many countries all over the world are adopting the legislation on "No Child is Left Behind by 2020" signed into law in January 2002 in the United States of America (USA).

In Singapore and Nigeria the studies attributed discipline problems in schools to unconducive home environment, negative peer pressure, lack of parental guidance or supervision, mass media which promoted negative materialistic and moral values, unrealistic curriculum, and weak school leadership. In Malasyia, Yahana (2009) and Nigeria (Nwagwa, 2007) studies reveals that a common pattern of discipline problems prevail in schools both in developed and developing countries. However, the problem of physical violence is more serious and frequent in occurrence in the developed countries than the developing ones. In Uganda research shows that striking of secondary students as a means of seeking attention or protest has been rampant. In the recent past, hardly did a term pass when a school would go on strike breaking the schooling pattern (Fiona, 2006). Nsubunga (2008) on his paper presented at the 5th ACP conference in Uganda on developing teacher leadership highlighted that the school administration had a duty to disseminate information to the students especially on issues pertaining to them if students' unrest was to be contained. Sound discipline is necessary if the school has to implement the curriculum effectively and to achieve maximum performance.

Students' discipline in Kenyan secondary schools has been a subject of debate in many forums. This is because instances of students' indiscipline lead to various negative consequences, such as destruction of school property, assault, indecent behaviour such as rape and in extreme cases death of students (Republic of Kenya, 1991). Such incidents tend to impact negatively on the gains made so far at this level of education. For example, death of students in the wake of school violence is a loss of valuable investment in human capital. On the other hand, destruction of physical infrastructure such as laboratories, dormitories and classrooms leads to loss of teaching time before new ones are built to replace the destroyed ones. Besides, putting up new infrastructure overburdens parents financially thereby possibly forcing those in the low-income bracket to withdraw their children from school. This has a high likelihood of increasing wastage at this level of education.

Kenya, however, relies heavily on the type of leadership that prevails in the institutions. In Incidents of students' indiscipline have led to various negative consequences, such as destruction of school property, assault, indecent behaviour such as rape (Republic of Kenya, 1991; Republic of Kenya, 2001). Kenya has also faced 
increased cases of indiscipline as documented by Mbiti (2007), Kindiki (2009), and Wanjiru (1999). Among the discipline problems experienced by Kenya Secondary Schools include truancy, bullying, destruction of school property, physical violence by students on teachers and other students. In Kenya, discipline in schools is equally a problem. Ngotho (2011) did a study and found that discipline problems are manifested in form of; drug and substance abuse, truancy, bullying, cheating in examinations and school riots among other ways.

Despite the efforts by the government, secondary schools continue to be confronted with problems arising from the inappropriate behavior of students which lead to strikes. Several studies Muli, (2011), Riang'a, (2013), King'ori, (2012), Mbogori (2012), Sang, Kiumi, and Mungai, (2009) have carried out to investigate the influence of principals' leadership styles on student discipline problems in secondary schools students in Kenya. However, there is paucity of research on principals' leadership practices and students' discipline not only in Kenya but more so in Makindu Sub County is one of the fast Sub County with 20 secondary schools among the 20 secondary school 11 have been reported to have strike of the student. Therefore it was on this basis that this study sought to establish principals' leadership practices and their influence on students' discipline management in public secondary school in Makindu Sub County, Kenya.

\section{Review of Literature}

A leadership style refers to a particular behavior applied by leaders to motivate his or her subordinates to achieve the objectives of an organization (Olembo, 1997; Kemp \& Nathan, 1989) identified three types of leadership names authoritarian, democratic and lassies faire. According to Campbell (1993) the autocratic leadership style results in the group members reacting aggressively and apathetically in work environment. Owens (1998) postulates that autocratic leadership centralizes power in the person of the leaders as well as ignoring the needs of the followers. In democratic leadership style the major point of focus is sharing. Olembo (1986) notes that leadership of a principal should be democratic, combining self-confidence, friendless, firmness and tact. It should not merely consist of issuing orders. Also says that the head leads better if he consults his staff and students from time to time on what is going on in the school.The principal shares decision making with the subordinates. He /she seeks discussion and agreements with all the stakeholders before a decision is taken (Durbin, 1998). He also observed that effective democratic school administration affect the trust level of students, teachers and parents. Griffins (1994) stated that the principal should endow each student with habits, self-respect and proper pride in his integrity that he will observe the norms of good conduct when not under compulsion or supervision and will carry them eventually into adult life. David (2007) study focused on the survey of the effectiveness of democratic school administration and management in one school division in Philippines. The implication of the study is that just like in Philippines school heads in Kenya who favour the use of democratic leadership attach the same level of trust to their students, teachers and parents in the administration of schools.

Discipline in the school is the function of the administration. The general school and even decision discipline is dependent upon the principals' administrative supervisory and leadership styles (Mwaura, 2006). The success of a school to a great extent depend upon its principal. He is the leader who must set the standard for hard work and good behavior. According to Olembo (1986) leadership of a principal should be democratic combining self-confidence, friendliness and firmness. It should not merely consist of issuing orders. Linda (1998) in her study concluded that principals should not be too autocratic in their leadership. They should not use tense body language being rigid or clench hands, insulting, humiliating or embarrassing teachers, students, support staff and even parents among others which will lead to indiscipline of students.

Okumbe 1998 noted that principals should encourage open door policy where student are free to see the head of the institution to explain their problems, should encourage students to bring new chamber as well as creative ideas, accept that he/she is capable of making mistakes, allow students to question his/her views, show no favorites and treat all students equally ,encouraging democratic form of school organization in which students elect their own leaders, provision of a suggestion box within the for students to give independent views about the school administration and even allowing students to have a say in determining the dress code of the school (Kyungu, 2002).

Mbogori (2012) conducted a study on influence of headteachers' leadership styles on students discipline in public secondary schools in Nairobi Province, Kenya. The study sought to achieve the following objectives: To investigate the influence of the headteachers' democratic leadership styles on students discipline. To investigate the influence the headteachers' autocratic leadership styles on students' discipline. To establish the influence of the headteachers' laisses -faire leadership styles on students' discipline. To establish whether other factors influence students discipline other than the headteachers leadership styles. The study was carried out in 12 public secondary schools in Nairobi province.

A review of related literature was carried out under the following sub titles; students discipline, the concept of leadership and leadership styles, head teacher's role on development of students discipline and other factors that may influence discipline in the school. The study used the descriptive survey design. Findings 
revealed that majority of the headteachers were considered democratic, followed by the autocratic while laissez -faire style of leadership received the least support. The study revealed that other factors such as home environment and mass media also has some influence on students' discipline. Therefore, based on the findings of the study, it was concluded that the leadership style of the headteacher has a considerable influence on students discipline in schools although other factors may come into play to impact on discipline.

Kuria (2012) carried out a study on influence of principals' leadership styles on students' discipline in public secondary schools in Kikuyu district in Kenya Five research objectives were formulated to guide the study. The sample consisted of 24 head teachers, 148 teachers and 360 students. The researcher used questionnaires to solicit data from the respondents. Both descriptive and inferential statistics were used to analyze the data. Findings revealed that head teachers use of autocratic leadership negatively influence $(-0.65)$ students discipline. This implied that the more autocratic styles are used, the poorer the student discipline.

Findings further revealed that there was very strong negative (-0.66) relationship between laissez-faire leadership and student discipline in secondary schools. Laissez-faire leadership style was not suited for use by head teachers because complete delegation without follow-up mechanisms created student discipline problems. The findings also revealed that there was no significant relationship between head teachers age gender and their leadership $(\mathrm{X} 2$ value $=5.267, \mathrm{df}=10, \mathrm{Sig}=: 0.691)$. A Chi square results $(\mathrm{X} 2$ value $=7.384, \mathrm{df}=10, \mathrm{Sig}=$ 0.882 ) revealed that there was no significant relationship between head teachers' experience and their leadership styles. King'ori, (2012) carried out a research on the influence of principals' leadership styles on students' discipline in public secondary schools in Tetu District, Kenya. The objectives of the study were: to establish the discipline issues in the schools, to establish if autocratic leadership style had an influence on students' discipline, to determine if democratic leadership style had an influence on students' discipline, to determine if laissez faire, transactional and transformational leadership styles had an influence on students discipline. The key findings of the study were that there were discipline issues in schools, most of the secondary school principals in the district applied autocratic leadership style at the expense of democratic, transformational and transactional leadership styles. The conclusion drawn was therefore that the application of autocratic leadership style was responsible for the discipline cases in the schools.

\section{Research Methodology}

The research design used in this study was descriptive survey. Descriptive survey is a method of collecting data by interviewing or administering a questionnaire to sampled individuals. The purpose of the survey is to describe existing conditions, identify the standards against which existing conditions can be compared, and investigate the relationships that may exist between events. (Creswell, 2003).Cohen, Manion \& Morrisson, (2000) explains that survey research involves collecting data to answer questions concerning the phenomenon under study and mostly uses questionnaire Descriptive survey also was also used to investigate phenomena by collecting samples to analyze and discover occurrences. This research design is deemed suitable to the study as the researcher will be interested in describing the principals' leadership practices and their influence on students' discipline management in public secondary school in Makindu Sub County, Kenya.

The target population comprise of all the 20 public secondary schools in Makindu Sub County. The target population of the study were 20 principals, 156 teachers and 1979 from form three and form four students. Data was collected by use of questionnaire and analyzed by use of Pearson's product moment correlation coefficient to establish the relationship between the independent and dependent variables.

\section{Results and discussions}

The study sought to establish how principals' leadership styles influence discipline amongst secondary school students. On a scale of $1-5$, The principals, teachers and students were asked to indicated their opinion how principals' leadership styles influenced discipline amongst secondary school studentsData collected from principals, teachers and students is presented in Table 1.

Table 1: Respondents' Views on the Influence of Principals' Leadership Styles and Secondary School Students' Discipline

\begin{tabular}{|c|c|c|c|c|c|}
\hline Statements & SA & $\mathbf{A}$ & $\mathbf{U}$ & D & SD \\
\hline & $\%$ & $\%$ & $\%$ & $\%$ & $\%$ \\
\hline \multicolumn{6}{|l|}{ Principals (PR) } \\
\hline $\begin{array}{l}\text { The principal encourage open door policy where students can access him or her and share their } \\
\text { problems and issues }\end{array}$ & 60.0 & 20.0 & 0.0 & 10.0 & 10.0 \\
\hline Encourage students to bring new creative ideas & 80.0 & 11.5 & 1.3 & 13.7 & 8.6 \\
\hline The principal consults with students before making changes on the school diet & 60.0 & 20.0 & 0.0 & 10.0 & 10.0 \\
\hline The principal allows students to have a say in determining the school dress code & 80.0 & 10.0 & 0.0 & 10.0 & 0.0 \\
\hline The principal sets aside specific day(s) in a week to discuss matters pertaining to the running of & 80.0 & 0.0 & 0.0 & 10.0 & 10.0 \\
\hline
\end{tabular}


Principals' Leadership Practices And Their Influence On Students' Discipline In Public .....

\begin{tabular}{|c|c|c|c|c|c|}
\hline the school with the students & & & & & \\
\hline \multicolumn{6}{|l|}{ Teachers (TR) } \\
\hline $\begin{array}{l}\text { The principal encourage open door policy where students can access him or her and share their } \\
\text { problems and issues }\end{array}$ & 66.6 & 9.7 & 3.9 & 12.3 & 7.5 \\
\hline Encourage students to bring new creative ideas & 64.9 & 0.0 & 0.0 & 10.0 & 10.0 \\
\hline The principal consults with students before making changes on the school diet & 80.7 & 4.9 & 3.3 & 10.1 & 6.4 \\
\hline The principal allows students to have a say in determining the school dress code & 70.2 & 11.8 & 1.3 & 12.7 & 4.0 \\
\hline $\begin{array}{l}\text { The principal sets aside specific day(s) in a week to discuss matters pertaining to the running of } \\
\text { the school with the students }\end{array}$ & 82.5 & 7.8 & 1.9 & 2.3 & 5.5 \\
\hline Students (ST) & & & & & \\
\hline $\begin{array}{l}\text { The principal encourage open door policy where students can access him or her and share their } \\
\text { problems and issues }\end{array}$ & 70.1 & 12.9 & 2.3 & 10.6 & 4.1 \\
\hline Encourage students to bring new creative ideas & 59.3 & 15.3 & 4.2 & 11.8 & 9.4 \\
\hline The principal consults with students before making changes on the school diet & 75.3 & 4.9 & 3.3 & 10.1 & 6.4 \\
\hline The principal allows students to have a say in determining the school dress code & 65.4 & 19.3 & 5.6 & 5.3 & 4.4 \\
\hline $\begin{array}{l}\text { The principal sets aside specific day(s) in a week to discuss matters pertaining to the running of } \\
\text { the school with the students }\end{array}$ & 71.9 & 9.1 & 2.9 & 13.6 & 2.5 \\
\hline
\end{tabular}

Key: SA = Strongly Agree; A = Agree; U = Undecided; D = Disagree; SD = Strongly Disagree

The data on the Table 1 reveals that a fair majority $(60 \% \mathrm{PR} ; 66.6 \% \mathrm{TR} ; 70.1 \% \mathrm{ST})$ of the sampled Principals, Teachers and Students strongly agreed with the view that principals in their respective secondary schools encourage open door policy where students are free to see the head of the institution to explain their problems. At the same time, $20.0 \%$ of the sampled Principals agreed as did $9.7 \%$ of the sampled Teachers and $12.9 \%$ of the Students. However, $0.0 \%$ of the sampled Principals, a paltry $3.9 \%$ of the sampled Teachers as well as $2.3 \%$ of Students were undecided, $10.0 \%$ of Principals as did $12.3 \%$ of the Teachers and $10.6 \%$ of the Students disagreed whereas $10.0 \%$ of Principals, $7.5 \%$ of the Teachers and $4.1 \%$ of the Students strongly disagreed.

These views corroborate the assertions of Adlam, (2003) who also noted that principals need to encourage open door policy where student are free to see the head of the institution to explain their problems, should encourage students to bring new chamber as well as creative ideas, accept that he/she is capable of making mistakes, allow students to question his/her views, show no favorites and treat all students equally, encouraging democratic form of school organization in which students elect their own leaders. At the same time, the study revealed that a fair majority (80\%PR; 64.9\%TR; 59.3\%ST) of the sampled Principals, Teachers and Students strongly agreed with the view that principals encourage students to bring new creative ideas. On the same breath, $0.0 \%$ of the sampled Principals agreed as did $11.5 \%$ of the sampled Teachers and $15.3 \%$ of the Students.

However, $0.0 \%$ of the sampled Principals, a paltry $1.3 \%$ of the sampled Teachers as well as $4.2 \%$ of Students were undecided, $10.0 \%$ of Principals as did $13.7 \%$ of the Teachers and $11.8 \%$ of the Students disagreed whereas $10.0 \%$ of Principals, $8.6 \%$ of the Teachers and $9.4 \%$ of the Students strongly disagreed. These findings also lend credence to the views expressed by Adlam (2003) who also asserted that principals need to encourage students to bring new chamber as well as creative ideas. The study also found out that a record majority (60\%PR; $80.7 \%$ TR; 75.3\%ST) of the sampled Principals, Teachers and Students strongly agreed with the view that principals consult with students before any changes are made to the diet provided by the school. At the same time, $20.0 \%$ of the sampled Principals agreed as did $7.6 \%$ of the sampled Teachers and $4.9 \%$ of the Students. However, $0.0 \%$ of the sampled Principals, a paltry $4.4 \%$ of the sampled Teachers as well as $3.3 \%$ of Students were undecided, $10.0 \%$ of Principals as did $5.2 \%$ of the Teachers and $10.1 \%$ of the Students disagreed whereas $10.0 \%$ of Principals, $2.1 \%$ of the Teachers and $6.4 \%$ of the students strongly disagreed.

In the same vein, the study revealed that an impressive majority (80\%PR; $82.5 \% \mathrm{TR} ; 71.9 \% \mathrm{ST})$ of the sampled Principals, Teachers and Students strongly agreed with the view that principals set aside specific day(s) in a week for meetings between the principals and the students to discuss matters pertaining to the running and of the school. These findings affirm the fact that principals' consultations should not merely consist of issuing orders, but involves sharing decision making with the subordinates. He/she seeks discussion and agreements with all the stakeholders before a decision is taken and trust students, teachers and parents.

To establish the relationship between frequency of principals' consultations and number of students' disciplinary cases, Pearson's Product Moment Correlation was calculated. The results are presented in Table 2. 
Principals' Leadership Practices And Their Influence On Students' Discipline In Public .....

Table 2: Pearson's Product Moment Correlation Test Analysis on Relationship between Frequency of Principals' Consultations and Number of Students' Disciplinary Cases

\begin{tabular}{|l|l|l|l|}
\hline \multicolumn{2}{|c|}{} & $\begin{array}{l}\text { Frequency of } \\
\text { Consultations }\end{array}$ & Number of Disciplinary Case \\
\hline \multirow{3}{*}{$\begin{array}{l}\text { Frequency of } \\
\text { Consultations }\end{array}$} & Pearson Correlation & 1 & $-.961^{* *}$ \\
\cline { 2 - 4 } & Sig. (2-tailed) & & .000 \\
\cline { 2 - 4 } & $\mathrm{N}$ & 13 & 13 \\
\hline \multirow{2}{*}{$\begin{array}{l}\text { Number of Disciplinary } \\
\text { Case }\end{array}$} & Pearson Correlation & $-.961^{* *}$ & 1 \\
\cline { 2 - 4 } & Sig. (2-tailed) & .000 & 13 \\
\cline { 2 - 4 } & $\mathrm{N}$ & 13 & \\
\hline \multirow{2}{*}{$* *$ Correlation is significant at the 0.01 level (2-tailed). } & & 13 \\
\hline
\end{tabular}

From Table 2, the results are presented in a matrix form such that the correlations are replicated. A Pearson Product-Moment Correlation was run to determine the relationship between frequency of principals' consultations and the number of students' disciplinary cases which generated strong negative correlation coefficients of $r=-0.961$ with corresponding significant level ( $p$-value) of 0.000 which was less than the predetermined level of significance, 0.05 , that is, p-value $=0.000<0.05$. These findings were statistically significant and thus indicate that there is significant relationship between principals' consultation of the student council and the number of students' disciplinary cases in school records.

\section{Conclusions and recommendations}

The study established that principals' leadership styles influence discipline amongst secondary school students. Majority of the sampled principals, teachers and students responded in favor principals in their respective secondary schools encourage open door policy where students are free to see the head of the institution to explain their problems. These findings affirm the fact that principals need to encourage open door policy where student are free to see the head of the institution to explain their problems, should encourage students to bring new chamber as well as creative ideas, accept that he/she is capable of making mistakes, allow students to question his/her views, show no favorites and treat all students equally, encouraging democratic form of school organization in which students elect their own leaders.

Principals encourage students to bring new creative ideas. That is, principals need to encourage students to bring new chamber as well as creative ideas. They allow students to have a say in determining the dress code of the school. These findings attest to the fact that encouraging democratic form of school organization in which students elect their own leaders, provision of a suggestion box within the for students to give independent views about the school administration and even allowing students to have a say in determining the dress code of the school. The study also established that principals set aside specific days in a week for meetings between the principals and the students to discuss matters pertaining to the running and of the school which affirms the fact that principals' consultations should not merely consist of issuing orders, but involves sharing decision making with the subordinates. He/she seeks discussion and agreements with all the stakeholders before a decision is taken and trust students, teachers and parents.

These findings were supported by conducting Pearson's Product-Moment Correlation Test Analysis on the relationship between frequency of principals' consultations and the number of students' disciplinary cases which generated strong negative correlation coefficients of $r=-0.961$ with corresponding significant level ( $p$ value) of 0.000 which was less than the predetermined level of significance, 0.05 , that is, $\mathrm{p}$-value $=0.000<0.05$. This implies that principals' consultation of the student council and the number of students' disciplinary cases in school have recorded a downward trend. Besides, principals who make several consultations anytime they need to make a decision concerning students have their schools experience fewer cases of students' infractions and cases of indiscipline minimized.

Based on the findings, the study recommended that principals should adopt leadership skills and mechanisms which are aimed at minimizing instances of students' indiscipline. School principals should organize for seminars and workshops for student leaders to acquire skills necessary to help reduce instances of indiscipline amongst their colleagues. Principals should adopt collaborative approach which brings all school stakeholders to help address students' indiscipline. Students should be sensitized on the importance of adherence to school rules and regulations Rules on the membership to the student council should be flexible to all students so that they can own its leadership. This will go a long way in guaranteeing respect to the leaders.

\section{References}

[1]. Adams, N. (2003). Secondary school management today. London, Melbourne, Sydney, Auckland Johannesburg, Hutchinson Ltd, Clandos Place

[2]. Blandford, S. (2008). Managing Discipline in School: London-Routledge.

[3]. Garagae, K. G. (2007). The Crisis of Student Discipline in Botswana schools. An Impact of Culturally Conflicting Disciplinary Strategies. Journal of Education Research and Review. University of Botswana 8017 
[4]. Gottfredson, E. (1990). School effectiveness and principals' effectiveness and Job satisfaction: A comparison of three school levels. The Alberta Journal of Educational Research 36 (3): 265-295.

[5]. Harllinger, L \& Heck, J. (2008). The four imperatives of a successful school. Thousand Oaks, CA: Corwin Press.

[6]. Imber, M \& W. A. Neidt. (1990) Teacher participation in school decision Making.Newsbury Park: Sage Publication Inc.

[7]. Itsueli, S. (2005). Education Supervision Perspective and Practical. Lagos: University of Ife Press.

[8]. Karunanayake, E. (2012). Management Concepts and Practices, Boston, Allyn and Bacon Company.

[9]. Kindiki, J. (2009). Effectiveness of Communication on Students Discipline in Secondary Schools in Kenya.Educational Research and Review. 4 (5), $252-259$.

[10]. Koechler, C. D. (2002) Personality Traits Associated with Transformational Leadership Styles of Secondary Principals in Christian Schools. PhD Dissertation, Kent: University, USA.

[11]. Mbiti, D. M. (1974). Foundations of School Administration. Nairobi: Oxford University Press.

[12]. Ngotho, A. (2011). Course of Students, Indiscipline in Public Secondary Schools in Mukurwe-ini District Unpublished Master Thesis, Nairobi University.

[13]. Nolle, D \& Chandler, K., (2007). Toward an explanation of variation in teachers' perceptions of transformational school leadership. Educational Administration Quarterly 32 (4), 512-538.

[14]. Nsubunga R. O., (2005).Human Resource Management Success in schools. Kampala.Net Media Publication. Ltd. Uganda

[15]. Nwagwa M. F. (2007). Measurement \& evaluation in education and psychology. Ado-Ekiti, Nigeria:AdebayoPublication\& Printing Press Nigeria Ltd.

[16]. Oak, M. (2008). Importance of Education to Youth. Retrieved from http://www.buzzle.com/articles/importance of education to youths.

[17]. Republic of Kenya (2001). Report of the Task Force on Student Discipline. Nairobi: Nairobi Government Press.

[18]. Schon, D. (2003). The reflective practitioner: how professionals think in action. New York: Basic Books.

[19]. Sergiovanni, (1998). The Principalship: A Reflective Practice Perspective. Boston London: Allyn and Bacon Company.

[20]. Yahana, M. F. (2009). Measurement \& evaluation in education and psychology(2nd ed.). Ado-Ekiti:Malaysia Adebayo Publishing and printing Press Ltd. 